\title{
E-Module Design Using Kvisoft Flipbook Application Based on Mathematics Creative Thinking Ability for Junior High Schools
}

\author{
https://doi.org/10.3991/ijim.v16i04.25329 \\ Setiyani $^{(\bowtie)}$, S.B Waluya, Y.L Sukestiyarno, Adi Nur Cahyono \\ Universitas Negeri Semarang, Semarang, Indonesia \\ setiyaniastudents.unnes.ac.id
}

\begin{abstract}
Mathematics learning innovations in teaching materials used in schools are still in the form of printed books from the government. In the 4.0 era, the use of technology can be used to make teaching materials in the form of e-modules or electronic modules using the Kvisoft Flipbook application. The purpose of this study was to determine the validity, practicality, and student responses to the design of the number pattern e-module based on mathematical creative thinking skills using the kvisoft flipbook application so that it can be used as a learning resource for students both in the classroom learning process and independent learning. The method used in this study is a research and development (R\&D) method using the ADDIE model. The data collection technique used is through a validation questionnaire, user practicality questionnaire and student response questionnaire to e-modules. The results of the study show that this e-module is very feasible to use with the results of material expert validation, media expert validation, user practicality, and student responses to e-modules. Based on the results of this study, the design of the e-module using the kvisoft flipbook maker application based on mathematical creative thinking skills is appropriate for use in the learning process for class VIII number pattern material.
\end{abstract}

Keywords — creative thinking ability, e-module, kvisoft flipbook

\section{Introduction}

The life of a global society that is entering the 21 st century requires human resources to have character, literacy, and competence to compete in the industrial revolution 4.0 [1]. The expected competence aspects are critical thinking, communication, collaboration, problem solving and creative skills [2]. Creative thinking is one of the competencies that students need to have, because with this ability students can solve problems [3], [4]. Mathematics is a subject taught at every level of education with the aim of preparing students for logical, critical, and creative thinking [5]. Creative thinking is a skill that must be developed in everyday life and make us accustomed when dealing with real life [6]. Creative thinking is the ability to think, act to solve problems in unusual, unique ways, and new aspects of regulation are original and useful. 
Students' creative thinking skills will not develop if it is not supported by the creativity of the teacher [7]. Creative and innovative teachers can make learning fun and use proper teaching materials. The use of teaching materials can be used in the form of printed books and e-books.

Based on observations at one school, the teacher uses a single textbook that only contains material and questions as support in the learning process, namely books printed from the government. Printed books from the government have not been able to make students understand the material and learn independently. This makes the development of creative thinking of students at the school still low. The learning process will be effective if it is supported by the availability of media, the availability of media and dynamic teaching methodologies, which allow for the development of student potential optimally [8]. Learning resources such as modules will make the learning process more effective, efficient, and relevant. It is hoped that the development of teaching materials can make students' mathematical creative thinking skills better [9].

Creativity is a term coined by Alfred North Whitehead who says that creativity is the principle of novelty. Use of Flash Flip Book Media in Information and Communication Technology Learning to Improve Student Learning Outcomes [10]. According to [11], the Torrance Test of Creative Thinking (TTCT) which is often used to measure the creativity of children and adults. The three components of creativity that are measured through the TTCT are novelty, flexibility, and fluency [12]. Meanwhile, according to [13] four aspects of creative thinking skills: fluency, flexibility, originality, and elaboration.

Based on the results of observations at Madrasah Tsanawiyah Mafatihul Huda, Cirebon Regency, it shows that the ability to think creatively in MTs is still low. There are still many found in solving problems, students only use the information obtained in general, namely by using formulas. As a result, students still have difficulty in solving more complex problems. Furthermore, when given a question that is different from the example, students are often confused in doing it. Figure 1 will show that the novelty aspect is still relatively low.

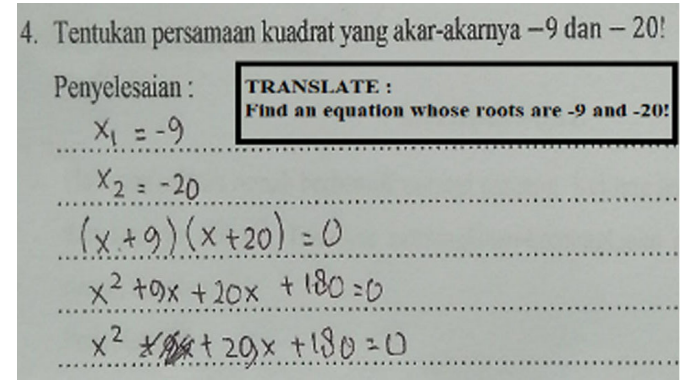

Fig. 1. Student's answer in preliminary stage

The results of initial observations provide information that students' mathematical creative thinking skills are still low. The category of the lowest creative thinking aspect is the novelty aspect, only 1 student out of 28 students can solve mathematical 
problems but is still not precise in the calculations. Creative thinking is an ability that is rarely considered when learning mathematics [14]. Students only imitate how to solve problems given by the teacher, so they tend to learn mathematical concepts by rote without deep understanding [15]. Things like this make students less able to think creatively and are not trained to do analysis before making decisions. Creative teachers must be sure that they can design creative activities, apply various learning resources, and provide opportunities for students to solve problems on their own, although all of this is not easy to carry out.

Advances and amazingly fast technological developments always create interesting ways to involve students in learning, meet educational needs [16] so that in the end superior and quality resources are formed. Currently, the teaching materials that students can use are not only printed books but can also take the form of electronic books (e-books). Teaching materials in the form of modules can be converted into electronic form so that they are given the term electronic module or virtual module [17]. By using electronic modules, students can understand independently and can also be used as learning notes. The main purpose of teaching materials is that the reader can absorb the material or reading material independently. To display innovative and creative e-modules, it is equipped with a combination of video, animation, and audio [18]. This combination is expected to help students visualize the abstract subject matter of mathematics so that it becomes concrete.

One of the media in creating electronic modules to create an innovative, creative, and efficient learning environment is the use of flipbooks. Flipbooks are a classic animation made from stacks of thick books resembling paper, on each page to illustrate the process of something moving [19]. Using Flash Flipbook media can increase student motivation and can also affect student learning outcomes or achievement [20].

Creating a multimedia-based learning environment is done using open-source software. The type of software is kvisoft flipbook maker which is used to make the appearance of books or other teaching materials in an animated digital book in the form of a flipbook. This type of kvisoft flipbook maker software can be downloaded for free over the Internet. Kvisoft Flipbook Maker is a software designed to convert PDF files to page-turning digital publications. This software can change the appearance of PDF files to be more attractive as an electronic book. The material will be presented in the form of e-modules using Kvisoft Flipbook Maker, namely number patterns. The material was studied in class VIII.

Several studies related to the development of e-modules using the kvisoft flipbook have been carried out. The "Assessment and Evaluation" e-module has a good category based on the results of expert assessments in the Asynchronous class [21]. E-worksheet using kvisoft flipbook obtained significant results on science process skills [22] as well as improving the critical thinking skills of chemistry teachers [23]. An e-module using the kvisoft flipbook was developed for the 5th semester mathematics learning course at Ahmad Dahlan University [24] and stoichiometric chemistry lessons [25]. Furthermore, student learning outcomes using kvisoft flip books are better than conventional books [26]. The previous studies can be seen from the results of Vosviewer as follows. 


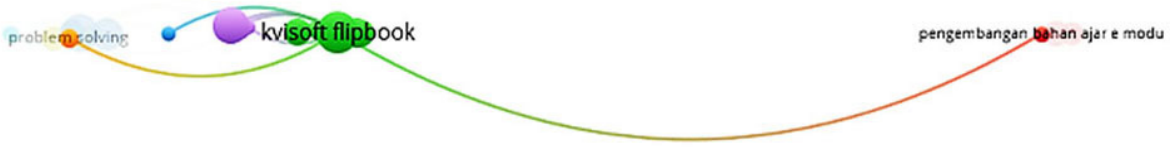

Fig. 2. Vosviewer output

Based on the results of the vosviewer output in Figure 2, there has been no research that has developed an e-module using kvisoft flipbook on number material specifically referring to the creative thinking ability of junior high school students. During the Covid-19 pandemic, the use of e-modules is an alternative and the right solution in online learning while still referring to how students learn. Therefore, the purpose of this research is to develop teaching materials in the form of e-modules based on mathematical creative thinking skills on number pattern material. The formulation of the problem in this study is how to develop an e-module of teaching materials in the form of an e-module based on mathematical creative thinking skills on number pattern material.

\section{Literature review}

\section{$2.1 \quad$ E-module}

The industrial revolution 4.0, which was marked by the era of technological disruption, had an impact on changes in the presentation of teaching materials, namely in the form of printed teaching materials, gradually switching to digital [27]. One of the teaching materials developed in digital/electronic formats is the e-module or electronic module [28]. Furthermore, e-modules are new innovations from conventional modules as a form of presenting independent learning materials that are systematically arranged in the smallest units to achieve certain learning goals [29]. The presentation of material in the electronic module is more interesting and communicative with the material delivered not only in text but also in the form of moving images or videos [30], so that it can attract students' interest with learning content that is more dynamic, effective, and fun [31]. The e-module display provides an attraction for students in studying the material presented by the teacher [32]. In addition, e-module allows students to repeat material that is not clear and provides opportunities for independent study [33]. Thus, students can control the speed of learning, provide easy access to material, and provide a meaningful learning experience [34]. Currently, the use of e-modules is very suitable, where the current generation has good digital literacy, an ardent desire to be independent, and applicable [35]. Even in recent years, e-modules have been widely used and integrated into curricula around the world [36].

The use of e-modules can also reduce the use of paper in the learning process so that it is more environmentally friendly than printed books [37]. In compiling the e-module, the creativity of teachers is challenged to present materials that are by the curriculum, student characteristics, materials, and learning objectives [30]. Students can open and use e-modules not only limited to rooms and meetings in the classroom, but students can study anywhere, anytime, with electronic modules [38]. A good e-module fulfills 
5 criteria, namely self-instructional, self-contained, stand-alone, adaptive, and user friendly [39]. Based on a literature review related to e-modules, it can be concluded that e-modules are electronic teaching materials that are systematically arranged to help students learn independently by paying attention to these five criteria.

\subsection{Kvisoft flipbook}

Flipbook is a book-shaped format that can add illustrations, animations, or images on each page [40]. Furthermore, the use of flipbooks is not boring because if each page is added with animation or moving illustrations it will match the animation or illustration added [41].

Kvisoft flipbook marker is software that is used to make the appearance of books or other teaching materials in an electronic book / module such as a flipbook or can add illustrations [24]. Furthermore, kvisoft flipbook maker is a reliable software designed to convert PDF files to digital publication pages or digital books [42]. This software can change the appearance of PDF files to be more attractive as a book. Besides, kvisoft flipbook maker can also create PDF files such as magazines, digital magazines, flipbooks, catalog companies, digital catalogs, and others.

Flipbook creation using kvisoft flipbook can add image files, SWF, FLV and MP4 video files and other formats. Meanwhile, the production or output of this software can be HTML, EXE, ZIP, and APP. The output HTML flipbook format allows you to upload it to a website for online viewing. The output as an EXE file can be opened without the help of an application.

Flipbook is a classic type of animation made with thick books resembling piles of paper, each page can be turned over and depicts something like moving [43], [44]. Some of the advantages of kvisoft flipbook include being able to create e-modules with displays not only text but also being able to insert sound, links, videos, animations and having design templates and features such as control buttons, navigation bars, hyperlinks, back sounds and backgrounds [45]. The advantages of this media are that it requires careful planning and a long time in designing illustrations on each page.

\subsection{Creative thinking skills}

The result of the ability to think creatively is understood as creativity. Creative thinkers can spontaneously see things from different angles that other people do not realize, see opportunities, and face the challenges of a rapidly evolving world [46]. Creative attitudes are at least as important as creative thinking skills. Gregoire describes creative thinking as "divergent thinking" [47]. Divergent thinking is the process of thinking through the creation of many ideas on a given topic in a brief time and ideas that are made in an abstract and unstructured form. Creative thinking skills in mathematics as the ability to develop structured thinking based on logic, didactic knowledge to connect mathematics in solving mathematical problems [48]. Creative thinking can be developed through realistic questions in the form of open questions where the teacher gives students the opportunity to look for several alternative solutions [49]. 
Lee and Jun distinguish between creative thinking abilities and creative personalities [50]. A person's creative thinking ability is based on four indicators [51]-[55] including: (1) fluency, namely the ability to provide many examples or statements related to certain concepts, fluent in opinion, giving answers, and solve problems, (2) Originality, namely the ability to think uniquely and unusually and able to provide new ideas (3) Flexibility, namely the ability to provide many ideas and answers, use various strategies and find various alternative solutions to problems, (4) Elaboration, namely the ability to develop ideas or products, enrich a situation so that it becomes more interesting and explain in detail. Meanwhile, a creative personality includes sensitivity, task commitment and curiosity.

\section{Methods}

This research is design research with the type of research used as the research and development method. According to [56] research and development methods or Research and Development is a research method used to produce a particular product and test the effectiveness of the product. The product resulting from this research is teaching materials in the form of e-modules using the kvisoft flipbook maker application based on students' mathematical creative thinking skills on number pattern material.

The research design that will be used in this research is the ADDIE development model. The ADDIE model is considered more comprehensive than other models based on the product development stage, this model is used for various forms of product development such as multimedia, especially in Indonesia [57]. The stages of ADDIE development design are Analysis, Design, Development, Implementation, and Evaluation [56] which are presented in the image below.

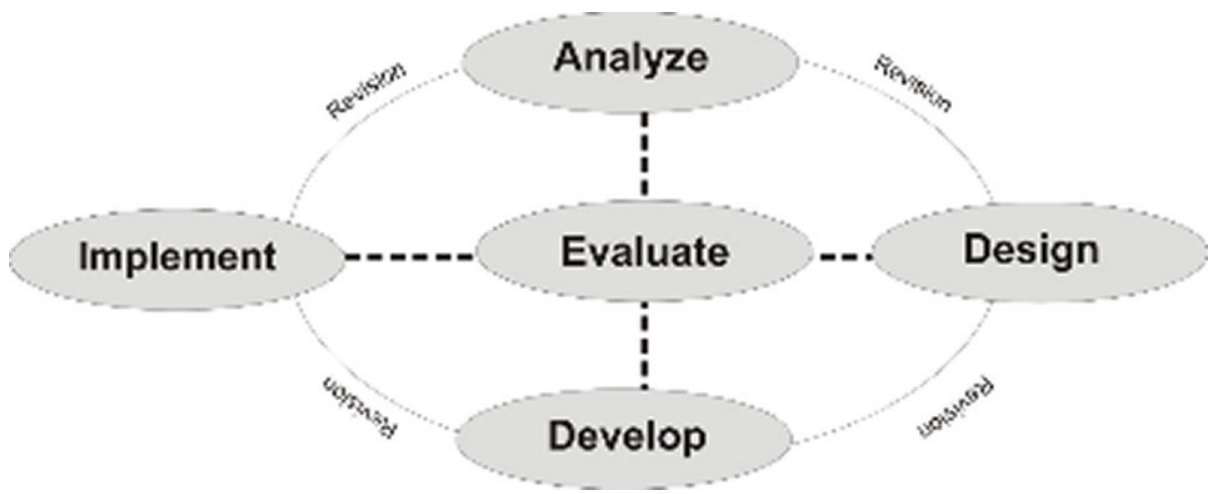

Fig. 3. ADDIE model development procedure [58]

This research only reached the development stage because of the limitations of the research problem, the formulation of the problem specified, and the limited time of the research. Evaluation is carried out at each stage of analysis, design, development and implementation. The description of the design at each stage is as follows: Analysis, namely conducting needs analysis, curriculum analysis, and analysis of student 
characteristics. Identifying problems by conducting preliminary studies in the form of essay questions based on mathematical creative thinking skills, identifying products that are suitable for the target, and thinking about the products to be developed. Design, the design stage is the stage of designing the product concept to be developed. Development, development is the process of making the design a reality. Implementation, as product trials to offer products that have been made. Evaluation, namely the process to see whether the product made is successful, following initial expectations or not.

The instruments in this study were validation sheets, practicality sheets and student response questionnaires after using the e-module. The aspects of material validation include relevance, presentation feasibility, language, and creative thinking skills. Aspects of media validation include e-module design, ease of operation, consistency, media format, navigation and animation effectiveness. The media and material validation sheets were filled out by experts, namely two material experts and 2 media experts. If the draft is not yet valid, it will be refined based on suggestions from material and media experts. The validated draft is then given to 3 users, namely the mathematics teacher to see its practicality. The practicality of the e-module was met by 3 teachers at Madrasah Tsanawiyah Mafatihul Huda Cirebon. Furthermore, the implementation stage is carried out on class VII Madrasah Tsanawiyah Mafatihul Huda as many as 9 students.

\section{$4 \quad$ Result and discussion}

This design research produces a mathematical learning device product in the form of an e-module on number pattern material. The e-module has been said to be feasible by material experts and also feasible to media experts. The data on the results of each stage of the research procedure carried out are as follows.

\subsection{Analyze stage}

The results of the analysis that have been carried out are used as guidelines and considerations in the preparation of mathematics e-modules. The analysis carried out includes needs analysis, curriculum analysis and analysis of student characteristics.

Needs analysis. The existence of learning media is needed to overcome the problems that occur in schools, especially in learning mathematics. As happened at Madrasah Tsanawiyah Mafatihul Huda, students' mathematical creative thinking skills are still relatively low. One of the reasons for this is that there are no interesting teaching materials that can accommodate these mathematical creative thinking abilities. The teaching materials used are not following the characteristics of students and tend to be conventional. The development of learning media is also oriented to technological advances in the current era because on the other hand the media used to date are still classified as old learning media such as print modules and printed worksheets.

Curriculum analysis. The curriculum that will be used for making this media is the 2013 Curriculum on number pattern material. The number pattern material was chosen in the design of the learning media module because it is one of the materials that is difficult to understand and is suitable for developing students' mathematical creative 
thinking skills. Therefore, learning media is needed that can make it easier for students to learn number pattern material based on mathematical thinking skills.

Analysis of student characteristics. From the results of interviews with teachers of mathematics class VIII at Madrasah Tsanawiyah Mafatihul Huda, the characteristics of students can be concluded as follows: 1) Students' lack of enthusiasm so that they consider mathematics as an unimportant subject. 2) Students still have difficulty in learning mathematics because most of them still have not mastered the pattern of mathematical numbers. 3) The low mathematical creative thinking ability of students. 4) Students do not have the enthusiasm to learn because the teacher is only limited to explaining. When the teacher explains the material, some students talk to other friends.

Based on needs analysis, curriculum analysis, and analysis of student characteristics, the researcher will develop an e-module based on mathematical creative thinking skills with the help of Kvisoft Flipbook Maker following the 2013 curriculum which discusses number pattern material. The e-module was created to overcome existing problems and aims to minimize students' assumptions that mathematics is difficult and so that students can easily understand the concepts in the number pattern material. E-modules are also made to minimize the role of teachers in learning so that students are expected to be more active in learning activities. The electronic module based on creative thinking skills was created using the Kvisoft Flipbook Maker application

\subsection{Design stage}

The design stages carried out in the product design stage of developing e-module learning media using the kvisoft flipbook application is module design preparation. The e-module learning media in its manufacture is assisted by using the Kvisoft Flipbook application using Frame $842 \times 595$. The making of the number pattern e-module based on mathematical creative thinking skills was previously typed in Microsoft Word first and then converted to pdf. There are several things that are done in the e-module design stage by using the kvisoft flipbook maker application.

The steps for compiling the e-module design include adjusting the competency standards and basic competencies as well as the syllabus based on the 2013 curriculum. The e-module teaching materials using the kvisoft flipbook maker application use A4 paper size; 1.5 spacing scale; Time New Roman font and the kvisoft flipbook maker pro 4.1.0 application.

The e-module design consists of front cover and back cover, introduction, preface, table of contents. The e-module consists of an introduction, instructions for use, concept maps, problems as an introduction to the material, learning videos, examples of questions based on mathematical creative thinking skills, seeing, and evaluation with questions based on mathematical creative thinking skills. Then there is a glossary or important words in the material, a bibliography, and an interesting animation so that students do not get bored during learning.

\subsection{Development stage}

The media begins to be made based on the design at the design stage. Furthermore, the finishing e-module is packaged in .exe and .swf formats. For this virtual module to 
be used and run properly on computer systems, it must have the following minimum specifications: Flash Player 10.0 or more, Windows $7 / \mathrm{XP} / 10$ operating system, memory RAM $4 \mathrm{~Gb}$, recommended higher, Hard Disk $500 \mathrm{~Gb}$ or more, minimum celeron processor or above, recommended Pentium core i3 or later generation.

The validity evaluation by material and media experts. The next step is to test the validity of the e-module by material experts and media experts. The recapitulation of the validation results by material experts is in Table 1 .

Table 1. Material expert validation results

\begin{tabular}{|l|c|c|}
\hline \multirow{2}{*}{\multicolumn{1}{|c|}{ Aspect }} & \multicolumn{2}{c|}{ Score } \\
\cline { 2 - 3 } & Validator 1 & Validator 2 \\
\hline Relevance & 44 & 42 \\
\hline Serving Eligibility & 28 & 24 \\
\hline Language & 20 & 18 \\
\hline Creative Thinking Ability & 12 & 11 \\
\hline Total & 104 & 95 \\
\hline Average & \multicolumn{2}{|c|}{99.5} \\
\hline Percentage/Category & \multicolumn{2}{|c|}{$95 \%$ / Very Valid } \\
\hline
\end{tabular}

The validity evaluation by media experts is in Table 2 .

Table 2. Media expert validation results

\begin{tabular}{|l|c|c|}
\hline \multirow{2}{*}{\multicolumn{1}{|c|}{ Aspect }} & \multicolumn{2}{c|}{ Score } \\
\cline { 2 - 3 } & Validator 1 & Validator 2 \\
\hline Screen Design & 13 & 13 \\
\hline Easy the Operation & 6 & 11 \\
\hline Consistency & 9 & 7 \\
\hline Format & 6 & 7 \\
\hline Sound & 8 & 8 \\
\hline Navigation Effectiveness & 8 & 15 \\
\hline Animation & 13 & 9.86 \\
\hline Total & 9 & \multicolumn{2}{|c|}{$87 \%$} \\
\hline Average & \multicolumn{2}{|c|}{ Very Valid } \\
\hline Percentage & \multicolumn{2}{|c|}{} \\
\hline Validity Category & \multicolumn{2}{|c|}{} \\
\hline
\end{tabular}

Based on the average score of material and media experts, it shows that the e-module is in the very valid category. This means that the quality of the e-module is considered valid and possible from the point of view of material experts and media experts. The next step, researchers made revisions according to the suggestions or inputs given by material experts and media experts. The suggestions or input from material experts and media experts to be improved are as follows. 
Media expert advice or feedback. At the media expert validation stage, there are suggestions or input to make the e-module better than before. The suggestions or inputs given by media experts are as Table 3 .

Table 3. Media expert suggestions or feedback

\begin{tabular}{|l|l|l|}
\hline No & \multicolumn{1}{|c|}{ Aspect } & \multicolumn{1}{c|}{ Suggestions or Feedback } \\
\hline 1 & Screen Design Display & $\begin{array}{l}\text { There is writing that is too small in size and pay attention to the color } \\
\text { contrast in the instructions for use }\end{array}$ \\
\hline 2 & Sound & The button for video playback needs to be clarified \\
\hline
\end{tabular}

Based on Table 3, suggestions or inputs given by media experts are that there are writings that are too small in size, and the color selection is not right, the instructions for use and buttons for music playback need to be clarified. The results of the improvements are following the media expert's suggestions as follows.

Screen design display. Before revision the size of the text in the user manual is too small, making the text unreadable. The User manual before revision can be seen in Figure 4.

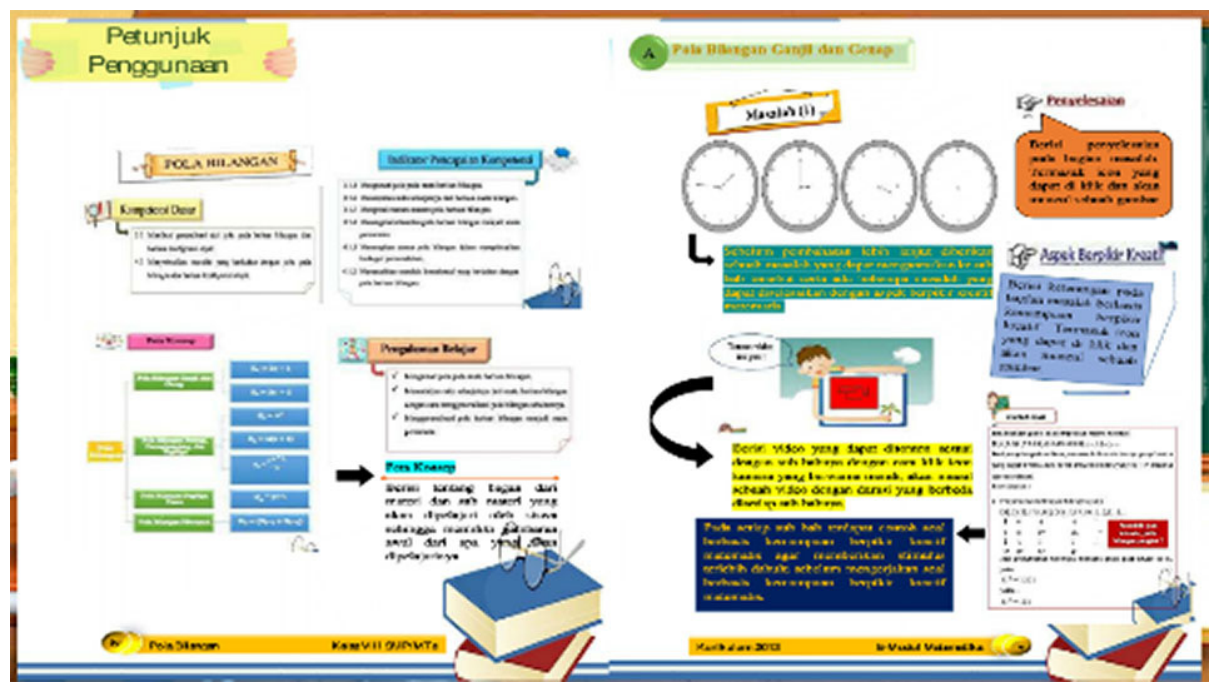

Fig. 4. Before revision

This part of the instructions is important to provide instructions in learning the e-module so that it is systematic, the authors improve the font size and color selection so that the writing is readable by e-module users. The User manual after revision can be seen in Figure 5. 


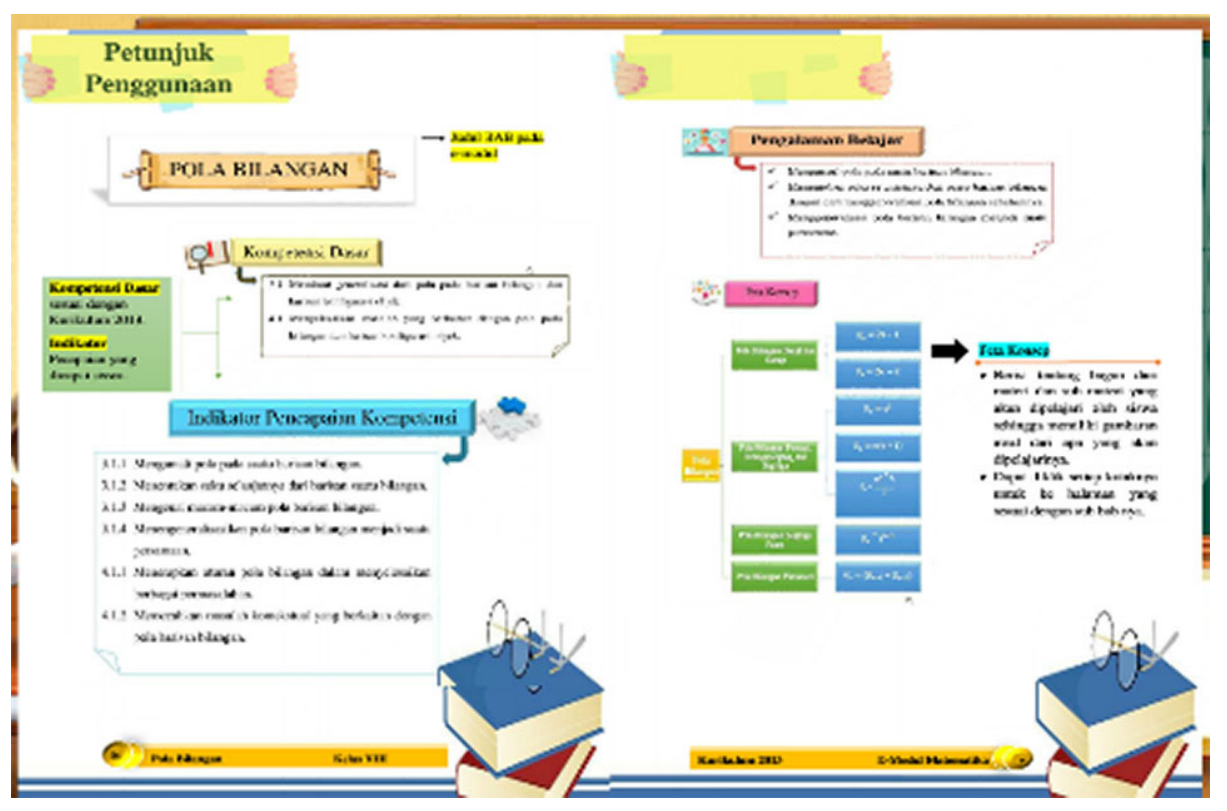

Fig. 5. After revision

Sound

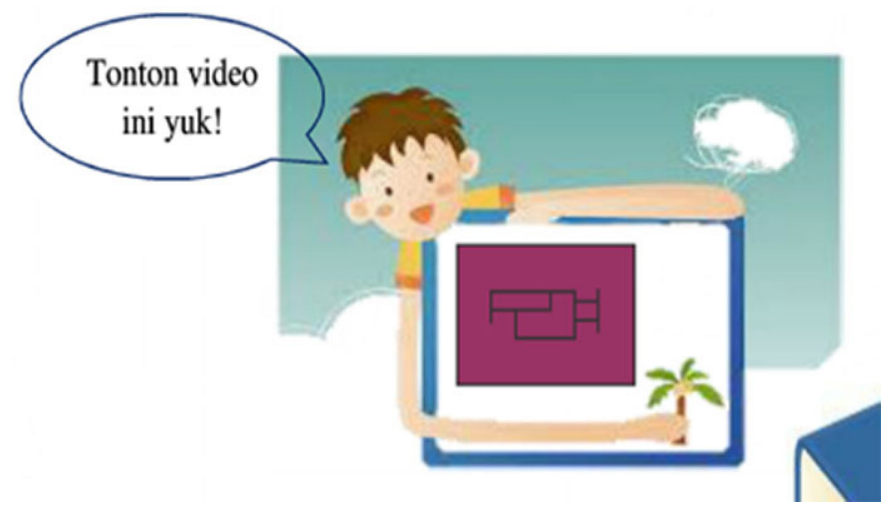

Fig. 6. Before revision 


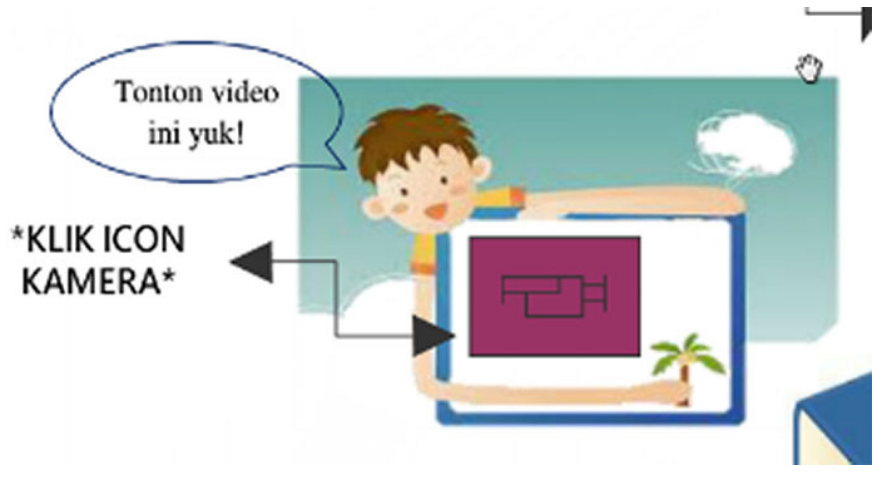

Fig. 7. After revision

In Figure 6, the button for video playback does not exist so that if the use of the e-module is not careful, the video will not play. Then the author corrects it by giving instructions to click the camera icon to play the existing video. It can be seen in Figure 7.

Suggestions or feedback from material experts. At the material expert validation stage, there are suggestions or input to make the e-module more perfect or more interesting than before. The suggestions or inputs given by material experts are as follows.

Table 4. Suggestions or feedback from material experts

\begin{tabular}{|l|l|l|}
\hline \multicolumn{1}{|c|}{ No } & \multicolumn{1}{|c|}{ Aspect } & \multicolumn{1}{c|}{ Suggestions or Feedback } \\
\hline 1 & Serving Eligibility & Fix ambiguous sentences in the questions \\
\hline
\end{tabular}

Based on Table 4, the suggestions or inputs given by the material experts are on the language evaluation questions used with multiple meanings, so it is necessary to correct the sentences in the evaluation questions to match the author's instructions for making questions. The results of the repair are following the advice of material experts as Figures 8 and 9.

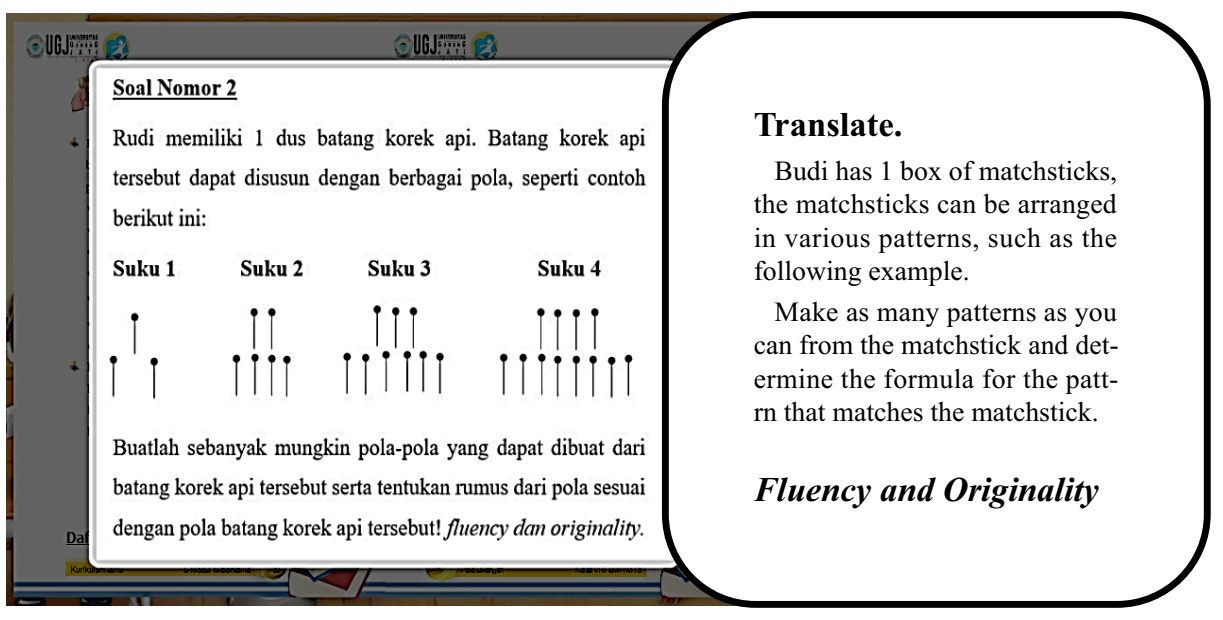

Fig. 8. Before revision 


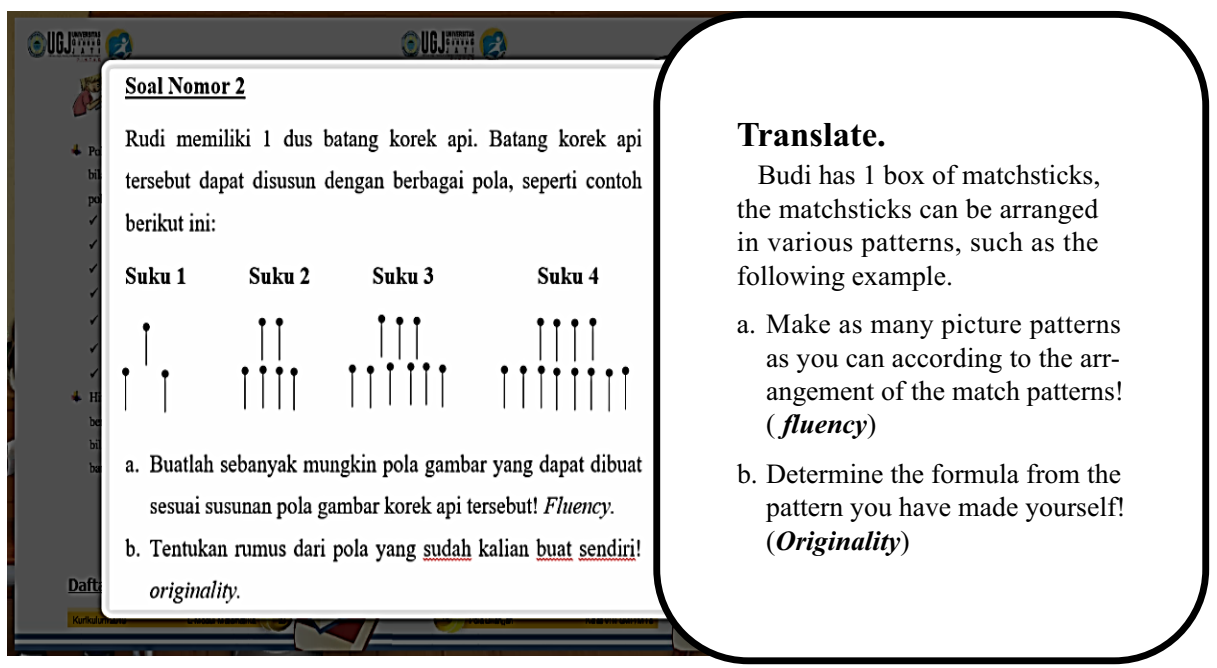

Fig. 9. After revision

The practicality e-module. Apart from the validation test results, there are also user practicality test results that were tested on 3 users by 3 Madrasah Tsanawiyah Mafatihul Huda teachers on e-modules that have been developed, overall getting an average percentage of $94 \%$ with very practical criteria to use. It can be seen in Table 5 .

Table 5. Suggestions or feedback from material experts

\begin{tabular}{|l|c|c|c|}
\hline \multirow{2}{*}{\multicolumn{1}{c|}{ Aspect }} & \multicolumn{3}{c|}{ Score } \\
\cline { 2 - 4 } & Subject-1 & Subject-2 & Subject-3 \\
\hline User Convenience & 3.5 & 3.75 & 4 \\
\hline Time Efficiency & 3.5 & 3.75 & 4.5 \\
\hline Benefit & 4 & 4 & 11.5 \\
\hline Total & 11 & 11.5 & 95 \\
\hline Percentage & 93 & 95 & \\
\hline Average & \multicolumn{3}{|c|}{ Very Practical } \\
\hline Validity Category & \multicolumn{3}{|c|}{} \\
\hline
\end{tabular}

After the e-module is declared valid by media experts and material experts as well as practical by users, then it is implemented in the number pattern learning process.

\subsection{Implementation stage}

After the e-module was declared valid and practical, then the e-module was implemented at Madrasah Tsanawiyah Mafathul Huda in October 2020. The e-module implementation consisted of 9 students with different levels, namely 3 people including the high group, 3 medium group, and 3 more people in the low group. The selection of several research subjects was conducted because teaching and learning activities were still 
limited due to the pandemic period. After the implementation was done, the researcher gave questions about the ability to think creatively on the number pattern material. One of the students' answers from the medium group is as follows.

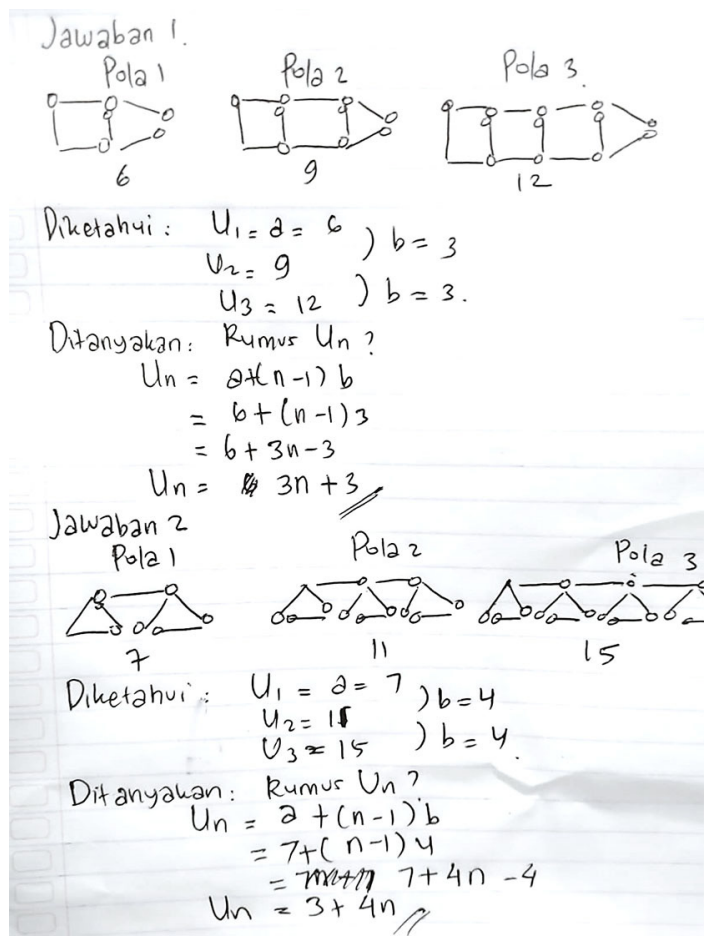

Fig. 10. Creative thinking skill in number pattern

In Figure 10, students can determine several patterns from match sticks. The patterns are then formed the formula for the $\mathrm{n}$ term. e-module is presented to provide a stimulus to students' creative thinking skills. Students work on the problems in the e-module according to their own ideas. Furthermore, in each lesson, the teacher provides reinforcement and motivation for students to try to think of new ways to answer questions. Based on the analysis of student responses to the e-module, the average percentage was 83.92. From the results of the interviews obtained, students have new experiences with learning.

\subsection{Evaluation stage}

Evaluation activities for e-module development using kvisoft flipbook are carried out in an integrated manner starting from the analysis, design, development, and implementation stages. The e-module produced through the ADDIE stage is assessed for validity, practicality, and effectiveness through the data analysis process. The quality of the e-module is enhanced through the results obtained from the assessment and input of 
the validator, the practicality of the users in this case is the mathematics teacher, student assessments and impressions, and the results of the creative thinking ability test. Based on these results, all students have finished studying the number pattern material with the help of e-module.

\subsection{Discussion}

E-module using the kvisoft flipbook application based on the mathematical creative thinking ability of junior high school students on number pattern material is an alternative learning resource that can be used online, blended learning or classroom learning. In this study, the e-module was considered valid by $95 \%$ of material experts and $87 \%$ of media experts. Both assessments are in the valid category. The results of this study are in line with the results of research by Rochsun and Agustin who developed an e-module on set material with valid categories [59]. The development of this e-module has become an innovation as well as a challenge for teachers to teach in a different way than usual [60]. For teachers who are not adaptive to IT advancements, they will stay in place, not trying anything new and relying only on books from the government. On the one hand, advances in technology and information can be reliable resources for creating meaningful learning both online and face-to-face, for example electronic modules, electronic whiteboards, etc [61].

Based on the results of the practicality of the user aspect, in this case a junior high school mathematics teacher, the e-module that has been developed is included in the practical criteria of $94 \%$. The kvisoft flipbook maker application helps in making e-modules that support adding animation, music, and learning videos to make the appearance of the e-module more attractive and not boring when it becomes a learning support so that the e-module has particularly good practicality. The results of this study are in line with Ilmi et. al, who developed an e-module using Adobe Flash Professional CS6 on trigonometry material with practical criteria based on teacher and student questionnaires [62]. E-module as an innovative teaching material is practically used anytime and anywhere [63].

The e-module which was developed with reference to the indicators of creative thinking received positive responses from students. 9 students who took part in learning using e-module achieved complete learning. The results of this study are in line with Patri and Heswari, who developed an ethnomathematics e-module to improve mathematical logical thinking skills [64]. E-module as a result of technological advances is not a panacea, but if its use is combined with a pedagogical approach, it has the potential to contribute to student learning outcomes [65]. Based on the results of research and theoretical studies, it can be defined that an e-module is a tutorial activity from the author in this case is a teacher delivered in writing so that its effectiveness is the same as face-to-face learning [66], [67]. Therefore, the e-module must be rich in activities designed by the teacher accompanied by clear instructions so that students can learn independently. This research has limitations, namely it involves few research subjects because Indonesia is still experiencing a pandemic period, so it is difficult to get permission from schools to carry out research involving many students. 


\section{Conclusion}

Based on research and discussion that the number pattern e-module using the kvisoft flipbook maker application based on mathematical creative thinking skills has been validated by material experts and media experts by obtaining valid or appropriate categories for use and the results of user trials obtaining practical categories in practicality assessment and good student responses. to this e-module. So, it can be concluded that the e-module design using the kvisoft flipbook maker application based on mathematical creative thinking skills on the subject of number patterns is appropriate to be used as a support in learning or learning media.

\section{Acknowledgment}

The authors would like to thank colleagues from Madrasah Tsanawiyah Mafathul Huda Kabupaten Cirebon.

\section{$7 \quad$ References}

[1] A. R. Sya'Roni, P. A. Inawati, and E. Guswanto, "Students' creative thinking skill in the flipped classroom-blended learning of mathematics based on lesson study for learning community," in Journal of Physics: Conference Series, 2020, vol. 1563, no. 1, p. 12046. https:// doi.org/10.1088/1742-6596/1563/1/012046

[2] W. E. Forum, New vision for education: Unlocking the potential of technology. British Columbia Teachers' Federation Vancouver, BC, 2015.

[3] D. Ismunandar, F. Gunadi, M. Taufan, and D. Mulyana, "Creative thinking skill of students through realistic mathematics education approach," in Journal of Physics: Conference Series, 2020, vol. 1657, no. 1, p. 12054. https://doi.org/10.1088/1742-6596/1657/1/012054

[4] B. Hokanson and R. Kenny, "Creativity and critique as formative processes in design thinking," J. Form. Des. Learn., vol. 4, pp. 2-4, 2020. https://doi.org/10.1007/s41686-020-00047-1

[5] S. B. Waluya and S. Mariani, "Mathematics literacy on problem based learning with Indonesian realistic mathematics education approach assisted e-learning edmodo," in Journal of Physics: Conference Series, 2016, vol. 693, no. 1, p. 12014. https://doi. org/10.1088/1742-6596/693/1/012014

[6] V. Švecová, L. Rumanova, and G. Pavlovičová, "Support of pupil’s creative thinking in mathematical education," Procedia-Social Behav. Sci., vol. 116, pp. 1715-1719, 2014. https://doi.org/10.1016/j.sbspro.2014.01.461

[7] C. Richardson and P. Mishra, "Learning environments that support student creativity: Developing the SCALE," Think. Ski. Creat., vol. 27, pp. 45-54, 2018. https://doi.org/10.1016/j. tsc.2017.11.004

[8] N. E. Ntobuo, A. Arbie, and L. N. Amali, "The development of gravity comic learning media based on Gorontalo culture," J. Pendidik. IPA Indones., vol. 7, no. 2, pp. 246-251, 2018. https://doi.org/10.15294/jpii.v7i2.14344

[9] G. Siemens et al., "Open learning analytics: An integrated \& modularized platform." Open University Press Doctoral dissertation, 2011.

[10] H. Whitehead, "SOCPROG programs: Analysing animal social structures," Behav. Ecol. Sociobiol., vol. 63, no. 5, pp. 765-778, 2009. https://doi.org/10.1007/s00265-008-0697-y 
[11] M. A. Runco, G. Millar, S. Acar, and B. Cramond, "Torrance tests of creative thinking as predictors of personal and public achievement: A fifty-year follow-up," Creat. Res. J., vol. 22, no. 4, pp. 361-368, 2010. https://doi.org/10.1080/10400419.2010.523393

[12] E. A. Silver, "Fostering creativity through instruction rich in mathematical problem solving and problem posing," ZDM, vol. 29, no. 3, pp. 75-80, 1997. https://doi.org/10.1007/ s11858-997-0003-X

[13] R. Rizal, D. Rusdiana, W. Setiawan, and P. Siahaan, "Creative thinking skills of prospective physics teacher," in Journal of Physics: Conference Series, 2020, vol. 1521, no. 2, p. 22012. https://doi.org/10.1088/1742-6596/1521/2/022012

[14] I. Krisdiana, T. Masfingatin, W. Murtafiah, and S. A. Widodo, "Worksheet-based learning research to improve creative thinking skills," in Journal of Physics: Conference Series, 2019, vol. 1254, no. 1, p. 12054. https://doi.org/10.1088/1742-6596/1254/1/012054

[15] R. Lince, "Creative thinking ability to increase student mathematical of junior high school by applying models numbered heads together," J. Educ. Pract., vol. 7, no. 6, pp. 206-212, 2016.

[16] S. Papadakis, M. Kalogiannakis, and N. Zaranis, "Comparing tablets and PCs in teaching mathematics: An attempt to improve mathematics competence in early childhood education," Presch. Prim. Educ., vol. 4, no. 2, pp. 241-253, 2016. https://doi.org/10.12681/ ppej. 8779

[17] N. R. Utami, A. Jufriadi, and H. D. Ayu, "Interactive e-module based on h-guided inquiry: Optimize the ict skills and learning achievements," Berk. Ilm. Pendidik. Fis., vol. 8, no. 3, pp. 183-195, 2020. https://doi.org/10.20527/bipf.v8i3.8604

[18] K. Supriadi, K. Ansari, and A. Adisaputera, "Development of module teaching materials writing short texts of literacy-based for students of Senior High School Parulian 1, Medan, Indonesia," Budapest Int. Res. Critics Linguist. Educ. J., vol. 2, no. 3, pp. 398-409, 2019. https://doi.org/10.33258/birle.v2i3.378

[19] F. R. Rahim, D. S. Suherman, and A. Muttaqiin, "Exploring the effectiveness of e-book for students on learning material: A literature review," in Journal of Physics: Conference Series, 2020, vol. 1481, no. 1, p. 12105. https://doi.org/10.1088/1742-6596/1481/1/012105

[20] E. Mindayula and H. Sutrisno, "Motivation level of student after implementation learning media based on 3D-pageflip," in 6th International Seminar on Science Education (ISSE 2020), 2021, pp. 283-288. https://doi.org/10.2991/assehr.k.210326.040

[21] D. G. H. Divayana, N. Santiyadnya, I. G. Ratnaya, I. G. Sudirtha, and I. P. Darmayasa, "Digital book for assessment and evaluation courses based on Kvisoft-kelase asynchronous pattern," Telkomnika, vol. 17, no. 1, pp. 328-336, 2019. https://doi.org/10.12928/telkomnika.v17i1.9764

[22] H. Asrial and M. Ernawati, "E-Worksheet for science processing skills using kvisoft flipbook," Int. J. Online Biomed. Eng., vol. 16, no. 3, 2020. https://doi.org/10.3991/ijoe. v16i03.12381

[23] M. Erna, E. Elfizar, and C. Dewi, "The development of e-worksheet using kvisoft flipbook maker software based on lesson study to improve teacher's critical thinking ability," Int. J. Interact. Mob. Technol., vol. 15, no. 1, 2021. https://doi.org/10.3991/ijim.v15i01.15679

[24] S. Fahmi, S. W. Priwantoro, R. A. Cahdriyana, A. Hendroanto, S. N. Rohmah, and L. C. Nisa, "Interactive Learning Media Using Kvisoft Flipbook Maker for Mathematics Learning," in Journal of Physics: Conference Series, 2019, vol. 1188, no. 1, p. 12075. https://doi.org/10.1088/1742-6596/1188/1/012075

[25] H. Nufus, S. Susilawati, and R. Linda, "Implementation of e-module stoiciometry based on kvisoft flipbook maker for increasing understanding study learning concepts of class X senior high school," J. Educ. Sci., vol. 4, no. 2, pp. 261-272, 2020. https://doi.org/10.31258/ jes.4.2.p.261-272 
[26] P. W. A. Suyasa, D. G. H. Divayana, and M. R. Kristiantari, "The effect of digital books based on kvisoft flipbook maker on student learning outcomes," in Journal of Physics: Conference Series, 2021, vol. 1810, no. 1, p. 12046. https://doi.org/10.1088/1742-6596/1810/1/012046

[27] H. Komikesari, M. Mutoharoh, P. S. Dewi, G. N. Utami, W. Anggraini, and E. F. Himmah, "Development of e-module using flip pdf professional on temperature and heat material," in Journal of Physics: Conference Series, 2020, vol. 1572, no. 1, p. 12017. https://doi.org/10.1088/1742-6596/1572/1/012017

[28] V. Serevina, "Development of e-module based on problem based learning (PBL) on heat and temperature to improve student's science process skill," Turkish Online J. Educ. Technol., vol. 17 , no. 3 , pp. $26-36,2018$.

[29] D. S. Sitorus, S. Siswandari, and K. Kristiani, "The effectiveness of accounting e-module integrated with character value to improve students'learning outcomes and honesty," J. Cakrawala Pendidik., vol. 38, no. 1, pp. 120-129, 2019. https://doi.org/10.21831/ cp.v38i1.20878

[30] R. Seruni, S. Munawaroh, F. Kurniadewi, and M. Nurjayadi, "Implementation of e-module flip PDF professional to improve students' critical thinking skills through problem based learning," in Journal of Physics: Conference Series, 2020, vol. 1521, no. 4, p. 42085. https:// doi.org/10.1088/1742-6596/1521/4/042085

[31] F. S. Irwansyah, I. Lubab, I. Farida, and M. A. Ramdhani, "Designing interactive electronic module in chemistry lessons," in Journal of Physics: Conference Series, 2017, vol. 895, no. 1, p. 12009. https://doi.org/10.1088/1742-6596/895/1/012009

[32] W. Istuningsih, B. Baedhowi, and K. B. Sangka, "The effectiveness of scientific approach using e-module based on learning cycle 7e to improve students' learning outcome," Int. J. Educ. Res. Rev., vol. 3, no. 3, pp. 75-85, 2018. https://doi.org/10.24331/ijere.449313

[33] R. M. Logan, C. E. Johnson, and J. W. Worsham, "Development of an e-learning module to facilitate student learning and outcomes," Teach. Learn. Nurs., vol. 16, no. 2, pp. 139-142, 2021. https://doi.org/10.1016/j.teln.2020.10.007

[34] N. Gaikwad and S. Tankhiwale, "Interactive E-learning module in pharmacology: A pilot project at a rural medical college in India," Perspect. Med. Educ., vol. 3, no. 1, pp. 15-30, 2014. https://doi.org/10.1007/s40037-013-0081-0

[35] T. Kistofer, G. S. Permadi, and T. Z. Vitadiar, "Development of digital system learning media using digital learning system," in 1st Vocational Education International Conference (VEIC 2019), 2019, pp. 177-182. https://doi.org/10.2991/assehr.k.191217.030

[36] Y. Kowitlawakul, M. F. Chan, S. S. L. Tan, A. S. K. Soong, and S. W. C. Chan, "Development of an e-Learning research module using multimedia instruction approach," CIN Comput. Informatics, Nurs., vol. 35, no. 3, pp. 158-168, 2017. https://doi.org/10.1097/ CIN.0000000000000306

[37] S. Sendari et al., "Developing e-module of environmental health for gaining environmental hygiene awareness," in IOP Conference Series: Earth and Environmental Science, 2019, vol. 245, no. 1, p. 12023. https://doi.org/10.1088/1755-1315/245/1/012023

[38] W. Kurniawan, K. Anwar, and D. A. Kurniawan, "Effectiveness of using e-module and e-assessment," Int. J. Interact. Mob. Technol., vol. 13, no. 9, 2019. https://doi.org/10.3991/ ijim.v13i09.11016

[39] P. E. D. Marvilianti and N. Sugihartini, "Development of e-modules entrepreneurship," in 3rd International Conference on Innovative Research Across Disciplines (ICIRAD 2019), 2020, pp. 311-316. https://doi.org/10.2991/assehr.k.200115.051

[40] I. Shcherbina, "The flipbook isn't half as scary as its antibook: On new book publishing formats," Russ. Stud. Lit., vol. 52, no. 1, pp. 30-47, 2016. https://doi.org/10.1080/10611975. $\underline{2016.1169092}$ 
[41] A. Nijholt, T. Romão, and D. Reidsma, Advances in Computer Entertainment: 9th International Conference, ACE 2012, Kathmandu, Nepal, November 3-5, 2012, Proceedings, vol. 7624. Springer, 2012. https://doi.org/10.1007/978-3-642-34292-9

[42] S. Saraswati and R. Linda, "Development of interactive e-module chemistry magazine based on Kvisoft Flipbook Maker for thermochemistry materials at second grade senior high school," J. Sci. Learn., vol. 3, no. 1, pp. 1-6, 2019. https://doi.org/10.17509/jsl.v3i1.18166

[43] I. Ladamay, F. N. Kumala, R. H. Susanti, N. Ulfatin, B. B. Wiyono, and S. Rahayu, "Designing and analysing electronic student worksheet based on Kvisoft Flip Book Maker for elementary school student," in IOP Conference Series: Materials Science and Engineering, 2021, vol. 1098, no. 3, p. 32028. https://doi.org/10.1088/1757-899X/1098/3/032028

[44] L. M. Samsu, M. Saiful, I. Fathurrahman, and H. Bahtiar, "Digitization of Takepan Sasak manuscipt based on the OPF flipbook," in Journal of Physics: Conference Series, 2021, vol. 1869, no. 1, p. 12073. https://doi.org/10.1088/1742-6596/1869/1/012073

[45] R. Linda, H. Nufus, and Susilawati, "The implementation of chemistry interactive e-module based on Kvisoft Flipbook Maker to improve student'self-learning," in AIP Conference Proceedings, 2020, vol. 2243, no. 1, p. 30011. https://doi.org/10.1063/5.0002309

[46] S. M. Ritter and N. Mostert, "Enhancement of creative thinking skills using a cognitivebased creativity training," J. Cogn. Enhanc., vol. 1, no. 3, pp. 243-253, 2017. https://doi. org/10.1007/s41465-016-0002-3

[47] J. Grégoire, "Understanding creativity in mathematics for improving mathematical education," J. Cogn. Educ. Psychol., vol. 15, no. 1, pp. 24-36, 2016. https://doi. org/10.1891/1945-8959.15.1.24

[48] B. Birgili, "Creative and critical thinking skills in problem-based learning environments," J. Gift. Educ. Creat., vol. 2, no. 2, pp. 71-80, 2015. https://doi.org/10.18200/ JGEDC.2015214253

[49] S. Agnoli, G. E. Corazza, and M. A. Runco, "Estimating creativity with a multiplemeasurement approach within scientific and artistic domains," Creat. Res. J., vol. 28, no. 2 , pp. 171-176, 2016. https://doi.org/10.1080/10400419.2016.1162475

[50] K. Lee and J. Jun, "Developmental characteristics of creative thinking ability and creative personality of elementary school children in Korea," Adv. Sci. Technol. Lett., vol. 92, pp. 46-51, 2015. https://doi.org/10.14257/astl.2015.92.10

[51] Z. Vally et al., "Examining the effects of creativity training on creative production, creative self-efficacy, and neuro-executive functioning," Think. Ski. Creat., vol. 31, pp. 70-78, 2019. https://doi.org/10.1016/j.tsc.2018.11.003

[52] S. Humble, P. Dixon, and E. Mpofu, "Factor structure of the torrance tests of creative thinking figural form A in Kiswahili speaking children: Multidimensionality and influences on creative behavior," Think. Ski. Creat., vol. 27, pp. 33-44, 2018. https://doi.org/10.1016/j. $\underline{\text { tsc. } 2017.11 .005}$

[53] L. Wang and D. Kokotsaki, "Primary school teachers' conceptions of creativity in teaching English as a foreign language (EFL) in China," Think. Ski. Creat., vol. 29, pp. 115-130, 2018. https://doi.org/10.1016/j.tsc.2018.06.002

[54] C. Lucchiari, P. M. Sala, and M. E. Vanutelli, "The effects of a cognitive pathway to promote class creative thinking. An experimental study on Italian primary school students," Think. Ski. Creat., vol. 31, pp. 156-166, 2019. https://doi.org/10.1016/j.tsc.2018.12.002

[55] H.-C. Kuo, Y.-C. Tseng, and Y.-T. C. Yang, "Promoting college student's learning motivation and creativity through a STEM interdisciplinary PBL human-computer interaction system design and development course," Think. Ski. Creat., vol. 31, pp. 1-10, 2019. https:// doi.org/10.1016/j.tsc.2018.09.001 
[56] S. Wahyuni, E. Erman, S. Sudikan, and B. Jatmiko, "Edmodo-based interactive teaching materials as an alternative media for science learning to improve critical thinking skills of junior high school students," Int. J. Interact. Mob. Technol., vol. 14, no. 9, 2020. https://doi. org/10.3991/ijim.v14i09.13041

[57] Y. Hanafi, N. Murtadho, and M. A. Ikhsan, "Reinforcing Public university student's worship education by developing and implementing mobile-learning management system in the ADDIE instructional design model," Int. J. Interact. Mob. Technol., vol. 14, no. 2, 2020. https://doi.org/10.3991/ijim.v14i02.11380

[58] G. Muruganantham, "Developing of E-content package by using ADDIE model," Int. J. Appl. Res., vol. 1, no. 3, pp. 52-54, 2015.

[59] R. Rochsun and R. D. Agustin, "The development of e-module mathematics based on contextual problems," Eur. J. Educ. Stud., vol. 7, no. 10, 2020.

[60] S. Poultsakis, S. Papadakis, M. Kalogiannakis, and S. Psycharis, "The management of digital learning objects of natural sciences and digital experiment simulation tools by teachers," Adv. Mob. Learn. Educ. Res., vol. 1, no. 2, pp. 58-71, 2021. https://doi.org/10.25082/ AMLER.2021.02.002

[61] L. C. Larson and T. N. Miller, "21st century skills: Prepare students for the future," Kappa Delta Pi Rec., vol. 47, no. 3, pp. 121-123, 2011. https://doi.org/10.1080/00228958.2011. 10516575

[62] R. Ilmi, I. M. Arnawa, and N. N. Bakar, "Development of an android-based for math e-module by using adobe flash professional CS6 for Grade X students of senior high school," in Journal of Physics: Conference Series, 2021, vol. 1742, no. 1, p. 12026. https://doi. org/10.1088/1742-6596/1742/1/012026

[63] J. Zhang, Z. Cai, Z. Zhao, and K. Ji, "Cell phone-based online biochemistry and molecular biology medical education curriculum," Med. Educ. Online, vol. 22, no. 1, p. 1374135, 2017. https://doi.org/10.1080/10872981.2017.1374135

[64] S. F. D. Patri and S. Heswari, "Development of ethnomathematic-based on mathematics e-module to improve students' logical thinking skills," in AIP Conference Proceedings, 2021, vol. 2330, no. 1, p. 40005. https://doi.org/10.1063/5.0043250

[65] S. Papadakis, "Advances in mobile learning educational research (AMLER): Mobile learning as an educational reform," Adv. Mob. Learn. Educ. Res., vol. 1, no. 1, pp. 1-4, 2021. https://doi.org/10.25082/AMLER.2021.01.001

[66] P. Yaniawati, A. L. Jasem, I. I. Supianti, S. Z. M. D. Osman, and A. S. Malik, "Using of sigil software in math education: e-module development and effects on self-regulated learning skills," J. Educ. Gift. Young Sci., vol. 9, no. 3, pp. 251-268, 2021. https://doi.org/10.17478/ jegys. 954829

[67] J. Vaiopoulou, S. Papadakis, E. Sifaki, D. Stamovlasis, and M. Kalogiannakis, "Parents' perceptions of educational apps use for kindergarten children: Development and validation of a new instrument (PEAU-p) and exploration of parents' profiles," Behav. Sci. (Basel)., vol. 11, no. 6, p. 82, 2021. https://doi.org/10.3390/bs11060082

\section{Authors}

Setiyani is doctoral students in the mathematics education department at the Universitas Negeri Semarang, Indonesia. The author works as a lecturer at the Universitas Swadaya Gunung Jati, Indonesia and a reviewer of the Infinity Journal, Indo-math, Wacana Akademika, Eduma, IJLTER, JNPM, and E-AJE. One of her articles was 
successfully published in the Journal on Mathematics Education (JME) indexed by Scopus (Q-2) in 2020. Email: setiyani@students.unnes.ac.id

Stevanus Budi Waluya is a Professor and works as lecturer postgraduate program at Universitas Negeri Semarang, Indonesia. His research interest include Differential Equation, Partial Differential Equation, Non Linear Oscillator, creative thinking skills, problem solving ability, lesson study, and mathematical literacy ability. He has collected 11 articles in Q-1 Journal. he is active in filling seminars/webminars related to the systematics of good journal writing and publications in international journals. Email: s.b.waluya@mail.unnes.ac.id

YL Sukestiyarno is a Professor and works as lecturer postgraduate program at Universitas Negeri Semarang, Indonesia. His research interest include creative thinking skills, problem solving ability, literacy numeracy, statistics, mathematical modelling, and augmented reality. He has collected 24 articles with scopus indexing. he is active in filling seminars/webminars related to the systematics of good journal writing and publications in international journals. Email: sukestiyarno@mail.unnes.ac.id

Adi Nur Cahyono is a Assoc. Professor and works as lecturer postgraduate program at Universitas Negeri Semarang, Indonesia. His research interest include creative thinking skills, digital technology, mobile app-supported math trail environment, math city map, augmented reality, STEM, and hybrid learning. He has collected 15 articles with scopus indexing. One of his book was successfully published in Springer International Publishing and the tittle is "Learning mathematics in a mobile app-supported math trail environment" in 2018. Email: adinurcahyono@mail.unnes.ac.id

Article submitted 2021-07-08. Resubmitted 2021-11-19. Final acceptance 2021-12-03. Final version published as submitted by the authors. 